\title{
DAMPAK PANDEMI COVID-19 TERHADAP SEKTOR PENDIDIKAN TERUTAMA BAGI PELAJAR
}

IMPACT OF THE COVID-19 PANDEMIC ON THE EDUCATION SECTOR ESPECIALLY

\author{
FOR STUDENTS
}

\author{
Nor Aisyah Amini \\ Program Studi Psikologi Fakultas Kedokteran Universitas Lambung Mangkurat \\ Jalan Jendral A. Yani Km. 36.00, Banjarbaru Kalimantan Selatan, 70714, Indonesia \\ E-mail : 2010914220029@mhs.ulm.ac.id
}

\begin{abstract}
ABSTRAK
Pandemi covid-19 tentunya bukan hanya merenggut nyawa banyak manusia, tetapi juga menyebabkan berbagai sektor harus melakukan perombakan kebijakan agar kegiatan bisa terus berjalan. Salah satu sektor yang terdampak adalah sektor pendidikan dimana pemerintah harus mengubah sistem pembelajaran yang semulanya dilaksanakan di dalam kelas menjadi pembelajaran dengan sistem daring atau secara online. Hal ini tentunya tidak dapat diterima langsung oleh seluruh pelajar dan orang tua yang ada di Indonesia. Pembelajaran daring ini menyebabkan banyak pelajar yang tertekan dalam segi psikis maupun jasmaninya karena ketidaksiapan dan ketidak mampuan dalam menghadapi perubahan sistem pembelajaran ini. Tujuan dari penelitian ini adalah untuk menjelaskan beberapa dampak yang dialami para pelajar dan para orang tua akibat dari sistem pembelajaran daring ini. Metode yang digunakan dalam penelitian ini adalah kajian literatur yang mana semua hasil penelitian diperoleh dari kajian-kajian yang berasal dari beberapa artikel terkait serta diambil dari kejadian-kejadian yang memang terjadi di sekitar penulis dimana penelitian ini menunjukkan dampak-dampak dari pembelajaran daring seperti banyaknya siswa yang merasa tertekan bahkan depresi karena tidak bisa mengikuti pembelajaran dengan baik atau juga karena proses adaptasi yang berjalan lambat, munculnya stres akademik yang berakibat pada menurunnya prestasi siswa, kesulitan memahami pelajaran karena kondisi lingkungan yang kurang kondusif, kurangnya interaksi antar siswa dengan teman-teman dan gurunya yang menyebabkan siswa menjadi jenuh dan tidak bersemangat dalam mengikuti pembelajaran, hingga dampak bagi kesehatan mata siswa karena terlalu lama berada di depan monitor. Namun, pembelajaran daring ini juga
\end{abstract}


menjadikan hubungan siswa dan orang tuanya menjadi lebih erat karena siswa mempunyai waktu lebih banyak untuk berkumpul bersama keluarga.

Kata Kunci : Dampak pandemi, covid-19, pendidikan.

\begin{abstract}
The Covid-19 pandemic has certainly not only claimed the lives of many people, but also has caused various sectors to reform policies so that activities can continue. One of the sectors affected is the education sector where the government has to change the learning system that was originally implemented in the classroom into learning with an online system or online. This of course cannot be accepted directly by all students and parents in Indonesia. This online learning causes many students to be depressed both psychologically and physically because of their unpreparedness and inability to deal with changes in this learning system. The aim of this study is to explain some of the impacts that students and parents experience as a result of this online learning system. The method used in this research is a literature review where all research results are obtained from studies that come from several related articles and are taken from events that do occur around the author where this research shows the effects of online learning such as the number of students. who feel depressed and even depressed because they cannot participate in learning well or also because of the slow adaptation process, the emergence of academic stress which results in decreased student achievement, difficulty understanding lessons due to unfavorable environmental conditions, lack of interaction between students and friends and teachers who cause students to become bored and not enthusiastic in participating in learning, so that the impact on students' eye health is due to being in front of the monitor too long. However, this online learning also makes the relationship between students and their parents closer because students have more time to gather with their families.
\end{abstract}

Keywords : The impact of a pandemic, covid-19, education.

Sudah hampir satu tahun lamanya, dunia digemparkan dengan kejadian luar biasa yang merenggut begitu banyak nyawa penduduk dunia. Kejadian luar biasa ini berasal dari Kota Wuhan, China dan diberi nama coronavirus atau yang biasa disebut covid-19 (Yamali \& 
Putri, 2020) [1]. Virus ini menyerang sistem pernafasan manusia yang menimbulkan flu hingga SARS dan penularan virus ini bisa dari berbagai macam hal, seperti batuk, bersin, bahkan bersentuhan fisik dengan orang yang terpapar covid-19 tersebut.

Pandemi Covid-19 bukan lagi menjadi permasalahan satu orang atau satu negara, tetapi kini pandemi Covid-19 telah menjadi permasalahan besar bagi seluruh dunia tidak terkecuali Indonesia. Ribuan jiwa telah menjadi korban dari virus ini hingga menyebabkan diberlakukanya Pembatasan Sosial Berskala Besar (PSBB) yang diberlakukan hampir di seluruh wilayah di Indonesia.

Pembatasan Sosial Berskala Besar atau PSBB yang tentunya memberikan banyak dampak pada berbagai sektor tidak terkecuali pendidikan. Berdasarkan penelitian yang telah dilakukan Hasan, Dinas Pendidikan terpaksa harus memutar otak untuk mencari solusi agar tetap terlaksananya pembelajaran di masa pandemi ini dan menghasilkan keputusan bahwa pembelajaran akan dilaksanakan secara daring tanpa adanya tatap muka secara langsung dan kegiatan praktik dilakukan melalui media video conference (dalam Abbas \& Erlyani, 2020) [9].

Kebijakan ini tentunya tidak dapat diterima langsung oleh masyarakat Indonesia terutama para pelajar dan orang tua karena sedikit banyaknya akan memberatkan mereka dalam hal fasilitas dan biaya untuk membeli kuota internet sebagai pendukung kegiatan pembelajaran. Selain itu juga perlu adanya pembiasaan, serta kesiapan mental untuk mendukung kelancaran sistem pembelajaran baru ini.

\section{METODE PENELITIAN}

Dalam penelitian kali ini, penulis menggunakan metode kajian literatur, dimana metode ini bertujuan untuk lebih mengetahui lebih dalam tentang dampak dari pandemi covid-19 terhadap proses pembelajaran yang dilakukan secara daring, yang kemudian berdampak pada kondisi jasmani dan psikis pelajar. Penelitian dan penulisan artikel ini didasarkan dari berbagai pengalaman yang terjadi pada masyarakat di sekitar penulis yang kemudian diperkuat dengan berbagai kajian-kajian yang terdapat dalam artikel-artikel yang sudah ada dan tentunya terbukti kebenarannya. 


\section{HASIL DAN PEMBAHASAN}

Pemerintah telah melakukan berbagai macam kebijakan untuk menekan angka penyebaran covid-19 ini, salah satunya adalah pemberlakukan Pembatasan Sosial Berskala Besar (PSBB). PSBB ini tentunya sangat membatasi aktivitas masyarakat hinga menyebabkan berbagai permasalahan baru salah satunya adalah dalam bidang pendidikan. Pada awalnya, pemerintah khususnya dinas pendidikan mengeluarkan kebijakan untuk meliburkan kegiatan pembelajaran selama 2 minggu dan disambut dengan suka cita oleh pelajar-pelajar di seluruh Indonesia karena hal ini tentu memberikan mereka waktu untuk rehat sejenak dan terlepas dari tugas dan ruang kelas beserta isinya. Namun kebahagiaan itu tidak berlangsung lama karena ternyata kasus positif covid-19 di Indonesia semakin meningkat dan menyebabkan libur sekolah harus diperpanjang dengan waktu yang tidak dapat ditentukan akan berlangsung berapa lama.

Jika sekolah diliburkan, maka hal itu tidak berlaku bagi tugas mereka sebagai pelajar. Sistem pembelajaran yang semulanya dilaksanakan secara tatap muka di ruang kelas, kini dialihkan menggunakan media pembelajaran online yang tentunya mengharuskan siswa dan orang tua menyiapkan alat pendukung agar mereka tetap bisa mengikuti pembelajaran seperti biasa. Permasalahan pertama dalam kebijakan ini adalah dimana tidak semua siswa dan orang tua paham bagaimana cara menggunakan media pembelajaran online tersebut bahkan tidak semua siswa dan orang tua yang mempunyai cukup biaya untuk menyediakan alat pembelajaran tersebut seperti ponsel android, tablet, laptop, ataupun semacamnya. Hal ini tentunya menjadi keluhan dari banyak orang tua karena menyebabkan mereka harus menjual beberapa aset berharga mereka untuk membeli alat-alat penunjang pembelajaran tersebut. Tak jarang juga kita temui anak-anak dan remaja-remaja yang akhirnya memilih berjualan dan bekerja untuk mengumpulkan uang demi membeli ponsel android untuk sekolah online.

Bukannya bisa bebas dari tugas, siswa justru "diserang" oleh tugas-tugas yang begitu banyak dan menumpuk. Hal ini tentunya menyebabkan banyak siswa yang merasa tertekan bahkan depresi hingga bunuh diri karena tidak tahan dengan sistem pembelajaran baru ini. Hal ini tentunya akan semakin memperparah kondisi mental siswa karena mereka langsung dihadapkan dengan sistem pembelajaran baru dan ditambah dengan serbuan berbagai macam tugas yang sebenarnya belum mereka pahami sepenuhnya sehingga berpotensi besar menyebabkan terjadinya stres akademik. Menurut Helman \& Kariv (2005), stres akademik terjadi apabila siswa mendapatkan tekanan dalam bidang akademik salah satunya adalah 
karena serbuan begitu banyak tugas yang harus dia selesaikan (dalam Kusuma dkk., 2020) $[3]$.

Salah satu faktor yang menyebabkan siswa menjadi tertekan bahkan depresi adalah kurang maksimalnya dan lambatnya proses penyesuaian diri siswa terhadap sistem pembelajaran baru yang memang terjadi dalam waktu yang begitu cepat ini. Menurut Sobri (2012), seseorang yang belum menyesuaikan dirinya terhadap berabagai macam beban akademik yang dia hadapi akan menjadikan dia jenuh dan mengalami stres akademik (dalam Kusuma dkk., 2020) [3]. Hal ini paling rentan dirasakan oleh siswa yang baru lulus dari bangku Sekolah Dasar ke Sekolah Menengah Pertama maupun dari Sekolah Menengah Pertama ke Sekolah Menengah atas bahkan juga dirasakan oleh para mahasiswa baru karena mereka buka hanya mengalami perubahan sistem pembelajaran tetapi juga perpindahan tingkat pendidikan. Menurut Azhari, dkk. (2016), pada saat siswa mengalami perpindahan jenjang sekolah maka mereka akan mengalami fenomena yang disebut top-dog atau kondisi dimana seseorang mengalami perpindahan dari status pelajar tertua dan terhormat di sekolah lamanya menjadi siswa baru yang berada ditingkat paling bawah dan harus hormat terhadap orang yang berada diatasnya [2].

Pembelajaran daring yang semua prosesnya dilakukan dari rumah ini juga mempengaruhi motivasi belajar siswa. Faktor pertamanya adalah lingkungan, dimana siswa yang biasanya belajar di sekolah dan di dalam ruang kelas kini harus belajar di rumah dengan berbagai macam kondisi yang terjadi entah itu keributan anggota keluarga lainnya ataupun kebisingan dari berbagai aktivitas yang terjadi di rumah itu yang menyebabkan konsentrasi siswa menjadi terpecah belah. Menurut Woolner, dkk. (2010), kegiatan belajar siswa yang terganggu akibat adanya kebisingan akan menyebabkan siswa tersebut menjadi sulit untuk memahami materi yang dia pelajari dan cenderung akan merasa jengkel karen konsentrasinya menjadi terganggu serta daya ingatnya terhadap materi tersebut pun juga akan terganggu karena dia tidak bisa berkonsentrasi penuh dalam menyimak materi yang dia pelajari (dalam Zwagery \& Dewi, 2019) [5]. Menurut Bell, dkk. (2010), kebisingan yang terjadi dalam waktu yang lama dan berulang-ulang yang berada di tingkat kebisingan melebihi $50 \mathrm{Db}$ bisa menimbulkan gangguan pada kesehatan manusia dalam hal komunikasi, pendengaran, hinga bisa menyebabkan stres karena dia tidak bisa berkonsentrasi dengan baik (dalam Pratiwi dkk., 2016) [10]. Selain itu perlu diketahui juga bahwa lingkungan sekolah mempunyai peran penting dalam proses belajar siswa. Dalyono (2012) mengungkapkan bahwa lingkungan sekolah mempunyai peran yang sangat penting dalam proses perkembangan intelektual siswa 
karena pola pikir siswa tersebut akan terus diasah ketika dia berada di lingkungan sekolah (dalam Aulia dkk., 2020) [6].

Selain mempengaruhi perkembangan intelektual, lingkungan sekolah juga mempengaruhi motivasi belajar siswa karena pembelajaran daring menyebabkan mereka hanya belajar sendiri di rumah tanpa adanya interaksi dengan teman-teman serta gurugurunya. Erich Fromm (1947) mengungkapkan bahwa terdapat lima hal yang begitu diperlukan manusia yang salah satunya adalah keterhubungan dengan hal-hal disekitarnya dan juga narsisme, karena dasar manusia yang merupakan makhluk sosial (dalam Abbas \& Erlyani, 2020) [9]. Tidak adanya keterhubungan inilah yang mengakibatkan siswa menjadi jenuh dalam belajar. Menurut Sutarjo (2014), kejenuhan belajar merupakan suatu masalah yang begitu banyak dan sering sekali dialami oleh siswa yang berdampak pada menurunnya motivasi belajar siswa dan menimbulkan rasa malas yang berakibat pada menurunnya prestasi siswa tersebut (dalam Kurniawan dkk., 2020) [7].

Bukan hanya berdampak pada psikis pelajar, pembelajaran daring ini juga sedikit banyak mempengaruhi kondisi jasmani siswa, salah satunya adalah kesehatan matanya. Pembelajaran online atau daring ini tentunya mengharuskan siswa untuk sering berhadapan dengan monitor handphone maupun laptop dalam kurun waktu yang relatif lama. Hal ini tentunya akan berdampak pada kesehatan mata siswa dan akan memperparah kondisi mata siswa yang memang sebelumnya sudah mengalami gangguan pada matanya. Hal ini dikarenakan mata yang terpapar langsung oleh sinar radiasi yang berasal dari berbagai produk elektronik yang digunakan sebagai media pembelajaran daring tersebut. Terdapat berbagai faktor yang mempengaruhi kesehatan mata seseorang. Menurut Mangkusumo, terdapat dua faktor yang mempengaruhi kesehatan mata seseorang, yaitu faktor intrinsik seperti tidak sehat atau kurangnya waktu tidur dan memang terdapat kelainan pada mata orang tersebut, serta faktor ekstrinsik seperti kurangnya pencahayaan pada ruangan tempat dia menggunakan media elektronik tersebut dan ukuran objek pada monitor mengharuskan otot-otot mata bekerja lebih keras dari biasanya (dalam Wulan dkk.) [4].

Namun, pembelajaran daring ini juga memberikan dampak positif dalam hal hubungan antara siswa dengan orang tuanya. Pandemi covid-19 yang menyebabkan semua aktivitas harus dilakukan dari rumah termasuk pendidikan dan pekerjaan yang otomatis menjadikan orang tua akan lebih punya banyak waktu untuk memantau perkembangan belajar anaknya bahkan bisa lebih memotivasi sang anak untuk terus bersemangat menjalani 
pembelajaran daring yang tentunya tidak mudah ini. Menurut Kocayoruk, dkk. (2014), semakin sering intensitas keterlibatan orang tua dalam memberikan dukungan terhadap anak akan semakin membantu anak dalam berbagai aspek seperti kesadaran dirinya, langkah yang dia ambil, dan tentunya kondisi kejiwaan anak (dalam Effendi dkk., 2020) [8].

Tentunya tidak ada yang berharap proses pembelajaran daring ini berlangsung secara terus menerus karena sudah menjadi rahasia umum bahwa pembelajaran ini telah merenggut banyak nyawa. Pemerintah Indonesia bersama dengan negara-negara lain pun saat ini sedang bekerja keras untuk menemukan vaksin dari covid-19 ini agar sistem tatanan kehidupan bisa berjalan normal kembali. Berdasarkan penelitian yang dilakukan Abbas (2020), bahwa dalam Hadist Riwayat Muslim, Rasulullah pernah besabda bahwa : "setiap penyakit yang ada, itu pasti ada penyembuhnya dan apabila obat yang tepat untuk menyembuhkan penyakit itu bisa ditemukan, maka penyakit itu pasti akan sembuh yang tentunya juga atas izin Allah" [11].

\section{SIMPULAN}

Pandemi covid-19 begitu banyak merugikan umat manusia entah itu menyebabkan begitu banyaknya nyawa yang harus menjadi korban hingga terganggunya kinerja berbagai aspek penting di suatu negara salah satunya Indonesia. Hal inilah yang akhirnya mendorong pemerintah untuk terpaksa memberlakukan berbagai perubahan sistem kerja, salah satunya adalah sistem pendidikan dimana pembelajaran diubah menjadi pembelajaran daring yang tentunya memberikan banyak dampak negatif maupun positif bagi masyarakat. Beberapa dampak negatif dari pembelajaran daring adalah banyaknya siswa yang merasa tertekan bahkan depresi karena tidak bisa mengikuti pembelajaran dengan baik atau juga karena proses adaptasi yang berjalan lambat, munculnya stres akademik yang berakibat pada menurunnya prestasi siswa, kesulitan memahami pelajaran karena kondisi lingkungan yang kurang kondusif, kurangnya interaksi antar siswa dengan teman-teman dan gurunya yang menyebabkan siswa menjadi jenuh dan tidak bersemangat dalam mengikuti pembelajaran, serta menyebabkan banyak siswa yang mengalami gangguan pada matanya karena terlalu sering terpapar sinar radiasi dari monitor yang dia gunakan saat pembelajaran daring berlangsung. Namun perlu diketahui bahwa pembelajaran daring ini juga memberikan dampak positif dimana siswa akan lebih mempunyai banyak waktu untuk berkumpul bersama keluarganya sehingga memudahkan orang tua untuk memantau dan memotivasi siswa agar lebih bersemangat mengikuti pembelajaran daring. 


\section{DAFTAR PUSTAKA}

[1] Yamali, F. R., \& Putri, R. N. (2020). Dampak Covid-19 Terhadap Ekonomi Indonesia. Ekonomis: Journal of Economics and Business, 4(2), 384-388.

[2] Azhari, M. A. S., Mayangsari, M. D., \& Erlyani, N. (2016). Hubungan Perilaku Asertif dengan Penyesuaian Diri pada Siswa Tahun Pertama di SMP. Jurnal Ecopsy, 2(1).

[3] Kusuma, A. D., Rachmah, D. N., \& Dewi, R. S. (2020). PERBEDAAN STRES AKADEMIK PADA SISWA YANG BERSEKOLAH FULL DAY DAN YANG TIDAK FULL DAY DI MAN TANAH BUMBU DAN MAN 3 BANJARMASIN. Jurnal Kognisia: Jurnal Mahasiswa Psikologi Online, 1(1), 55-62.

[4] Wulan, C., Faisal, M. A., \& Bakhriansyah, M. PERBANDINGAN KELUHAN MATA AKIBAT PENGGUNAAN MONITOR KOMPUTER JENIS CATHODE RAY TUBE (CRT) DAN LIQUID CRYSTAL DISPLAY (LCD) PADA MAHASISWA FAKULTAS KEDOKTERAN UNLAM.

[5] Zwagery, R. V., \& Dewi, R. S. PENGARUH KEBISINGAN TERHADAP DAYA INGAT PADA REMAJA.

[6] Aulia, R., Rachmah, D. N., \& Yuserina, F. (2020). HUBUNGAN ANTARA IKLIM SEKOLAH DENGAN KESADARAN DIRI PESERTA DIDIK KELAS IX DI MTSN 2 BANJAR. Kognisia prodi Psikologi FK ULM, 2(2), 43-48.

[7] Kurniawan, D. R., Akbar, S. N., \& Rusli, R. (2020). HUBUNGAN INTERAKSI TEMAN SEBAYA DENGAN KEJENUHAN BELAJAR PADA SANTRI ALIYAH PONDOK PESANTREN AL FALAH PUTRA BANJARBARU. Kognisia prodi Psikologi FK ULM, 1(1), 48-54.

[8] Effendi, M. F., Akbar, S. N., \& Rachmah, D. N. (2020). HUBUNGAN ANTARA DUKUNGAN SOSIAL ORANG TUA DENGAN KESADARAN DIRI PADA SISWA SMPN 8 BANJARMASIN. Kognisia prodi Psikologi FK ULM, 2(1), 6165. 
[9] Abbas, E. W., \& Erlyani, N. (2020). Menulis di Kala Badai Covid-19.

[10] Pratiwi, J. S., Anward, H. H., \& Febriana, S. K. T. (2016). Hubungan antara Persepsi terhadap Kebisingan dengan Stres Karyawan. Jurnal Ecopsy, 1(1).

[11] WARMANSYAH ABBAS, E. R. S. I. S. (2020). Menulis di Era Covid-19: Memanage Trauma Psikologis Menghindari Psikosomatis. Menulis di Era Covid-19: Memanage Trauma Psikologis Menghindari Psikosomatis. 